\title{
Self-Control and Subjective Volitional Regulation \\ as Personal Predictors of High School Students Success \\ in the Framework of Career-Oriented Education \\ in High School
}

\author{
Ludmila I. Dementiy and Victoria E. Kupchenko* \\ Omsk F.M. Dostoevsky State University \\ 55a Mira, Omsk, 644077, Russia
}

Received 06.09.2014, received in revised form 21.10.2014, accepted 24.11.2014

\begin{abstract}
The article provides a theoretical overview of research reflecting correlation between intellectual factors, motivational and personality variables with high school students' academic performance. This empirical research analyzes subjective volitional control, self-regulation, achievementmotivation, locus of control, intellectual abilities and temperamental characteristics which are considered important factors for predicting high school students' academic performance in the context of professional education. The study indicates the difference between indicators of standardized self assessment techniques developed for students and the outcome of teachers' evaluation of students' self-regulation during learning process. The research results suggest that a high level of subjective volitional control of high school students is an essential factor for professional education, while self-regulation is the most crucial facet when teaching less successful students. Students' academic performance in careeroriented classes is largely affected by their perseverance and intellectual abilities.
\end{abstract}

Keywords: Subjective Volitional Regulation; Self-Control; Career-Oriented Education.

Research area: psychology.

The primary goal of contemporary system of education is to provide students with necessary competencies. The earlier students acquire and develop these competencies, the more likely they will succeed in professional training courses. Modern Russian schools are actively implementing various comprehensive earmark programs within various priority domains the most important of which is transition to professional education. From our perspective, the idea of professional training in high school is directly related to the fundamental ideas of competency-based approach. The effectiveness of professional education has not received much attention until recently.

Early professional orientation, students' inability to choose a specialization, parents' making a decision for their children among many other factors have put the problem of finding predictors of effectiveness of academic and professional training in the center of attention. A number of research papers consider intellectual

(C) Siberian Federal University. All rights reserved

* Corresponding author E-mail address: dementiy@univer.omsk.su 
abilities, temperamental traits and motivational variables as personality characteristics which allow us to predict students' academic performance. The research data provided by foreign and Russian researchers suggests a moderate correlation between intellectual abilities and academic success. The results of the meta-analysis conducted by Poropat (Poropat, 2009), who evaluated a sample of over 70,000 students, show that the correlation between conscientiousness and academic performance appear to be of moderate magnitude: $\mathrm{r}=0.22$ and $\mathrm{p}=0.46$. The data on the role of motivational factors (intrinsic motivation, achievement motivation, goal specificity, perseverance and self-efficacy) in academic achievement is "very often inconsistent and controversial, which can be explained by peculiarities of learning environment, differences in measuring instruments and theoretical constructs as well as other factors" (Гордеева, Осин, 2012).

A great deal of research conducted by a number of foreign psychologists has proven that the most significant factor, which leads to successfulness in a wide range of life domains and situations, is an individual's ability to selfregulate. Individuals with typically high level of self-regulation tend to control unwanted impulses more effectively (Mischel at al, 1996), they are less likely to develop deviant behavior, and they are more successful in their interpersonal relationships (Tangney at al, 2004). W. Mischel has demonstrated that pre-school students with a consistently low level of self-control show worse academic achievement ten years later (Mischel at al, 1988).

Neuroticism and, to some degree, consent and openness to experience have appeared to be significant predictors of academic performance among a sample of Russian students (Кочергина, Най \& Орел, 2013). Test results have shown no statistically important relations between the level of volitional control and academic achievements (Батоцыренова, 2013). Моросанова В.И., Фомина Т.Г., Ковас Ю.В notice that "selfregulation is a meta-systematic factor for mobilization of cognitive and personality characteristics of an individual in setting and achieving goals in a variety of activities" (Моросанова и др., 2014). It is important to note that some results require verification and further consideration.

The controversy of the data on the contribution of self-control into academic performance as well as the lack of extensive research on predictors of academic success and efficacy of career-oriented education determined the scope of our research.

In the present study we hypothesized that self-control, volitional regulation, achievement motivation, intellect, and temperamental characteristics (need for cognition) mutually affect the effectiveness of career-oriented education.

\section{Method}

Participants. The selected respondents were high school students from Omsk who are taking classes gearing towards professional fields: physics and mathematics (41), social studies and economics (20); and general classes (18). The total number of participants is 79 . For physics and mathematics program, career-oriented classes include Mathematics, Physics, Informatics and Information and Communications Technologies; for social studies and history program, Mathematics, Social Studies, and Economics.

Procedure. In two experiment sessions, the subjects were asked to respond to a volitional subjective control questionnaire (Эйдман, 2010); a self-control scale (Brief Self-Control Scale; Баумайстер, 2004); a locus of control questionnaire (LC; Ксенофонтова, 1999); an achievement motivation questionnaire (Мехрабиан, 1987); the structure of temperament questionnaire (Русалов, 2003); and intelligence 
structure test (Amthauer, 2002). To identify indicators of self-control manifestations in the learning process, an additional questionnaire was provided to those subjects who had a high level of variables such as perseverance, attentiveness, impulsiveness, aggressiveness, and disciplinary offences. The manifestation of the same behavioral indicators was evaluated by school instructors who acted as experts in our study. The indicator of the students' academic success was an average grade in career-oriented classes in the 10th and 11th grade. To process the obtained results, the following methods of mathematical data analysis were applied: initial descriptive statistics; comparison of independent samples analyzed with the Mann-Whitney $U$-test; correlation analysis (Pearson correlation coefficient); and a multiple regression analysis.

The article focuses mainly on the description of the results on the level of self-control among high school students, its effect on academic performance of students taking career-oriented classes and the correlation between selfcontrol as well as other personality variables such as intellectual abilities and responsibility motivation.

\section{Results and Discussion}

Comparative analysis results. At the first stage of data processing, we determined the level of subjective volitional control and self-control among high school students using standardized questionnaires (see Table 1).

The data shows that high school students who took career-oriented classes and general classes demonstrate a high level of subjective volitional control and a moderate level of self-control.

The comparison of the expert survey data with the results of students' self-assessment of self-control indicators allowed us to distinguish two sub-groups of students with correlated and uncorrelated judgments.Thirtynine percent of the students scored high on self-control, perseverance, while they scored low on aggressiveness, impulsiveness, and disciplinary offences, which coincided with the instructors' assessment. Ten percent of the respondents scored a high on impulsiveness and disciplinary offences, which corresponded with the instructors' evaluation. On other self-control parameters, students' judgments significantly departed from instructors' assessments. Accordingly, $51 \%$ of high school students' provided assessments of self-control which consistently deviated from the instructors' assessments. Based on these results, students were grouped into the following categories: group 1, students with correlated high score on self-control; group 2, students with a correlated low score on self-control; group 3, students

Table 1. Subjective volitional control and self-control among high school students taking career-oriented classes and general classes

\begin{tabular}{|l|c|c|c|c|c|c|}
\hline \multirow{2}{*}{ Type of program } & \multicolumn{2}{|c|}{ General } & \multicolumn{2}{c|}{$\begin{array}{c}\text { Social studies } \\
\text { and economics }\end{array}$} & \multicolumn{2}{c|}{$\begin{array}{c}\text { Physics } \\
\text { and mathematics }\end{array}$} \\
\cline { 2 - 8 } Self-control indicators & $\mathrm{X}$ & $\Sigma$ & $\mathrm{X}$ & $\Sigma$ & $\mathrm{X}$ & $\Sigma$ \\
\hline General level of subjective volitional control & 14,5 & 3,85 & 15,29 & 3,71 & 13,68 & 5,00 \\
\hline Perseverance & 10 & 3,0 & 10,79 & 2,86 & 9,46 & 3,46 \\
\hline Self-restraint & 7,56 & 1,6 & 7,64 & 1,6 & 7,15 & 2,50 \\
\hline General level of self-control & 116 & 12,95 & 117 & 15,74 & 116,7 & 19,69 \\
\hline
\end{tabular}

Note. X-mean value, $\sigma$ - standard deviation 
Table 2. Data on standard questionnaires indicating the level of students' self-control and self-evaluation judgments

\begin{tabular}{|c|c|c|c|}
\hline $\begin{array}{l}\text { Groups of students with different level } \\
\text { of self-control } \\
\text { Indicators }\end{array}$ & $\begin{array}{l}\text { Correlated high } \\
\text { score on self- } \\
\text { control }\end{array}$ & $\begin{array}{l}\text { Correlated low } \\
\text { score on self- } \\
\text { control }\end{array}$ & $\begin{array}{l}\text { Uncorrelated } \\
\text { assessments of } \\
\text { self-control }\end{array}$ \\
\hline $\begin{array}{l}\text { General level of volitional self-control (Зверков, } \\
\text { Эйдман) }\end{array}$ & $12.1^{* *}$ & $18.4 * *$ & 14.4 \\
\hline Perseverance Scale (Зверков, Эйдман) & $8.58 *$ & $12.6^{*}$ & 9.8 \\
\hline Self restraint scale (Зверков, Эйдман) & 6.48 & 9.6 & 7.5 \\
\hline Brief Self-Control Scale; Баумайстер & 116 & 123.6 & 115.9 \\
\hline $\begin{array}{l}\text { Grade Point Average (GPA) }{ }^{1} \text { in career-oriented } \\
\text { classes }\end{array}$ & $4.08 * *$ & $3.4^{* *}$ & 3.7 \\
\hline
\end{tabular}

Note. ${ }^{*}$ - statistical significance $(\mathrm{p}<0.01),{ }^{*}$ - statistical significance $(\mathrm{p}<0.05)$

provided uncorrelated assessments of selfcontrol (see Table 2).

The correlation between the results of standardized self-control questionnaires conducted in groups with different assessments of self-control indicators using the MannWhitney $U$ test allowed us to discover significant differences for the general indicator of subjective volitional control among students with correlated high and low score on self-control $(\mathrm{U}=10.5$, $\mathrm{p}<0.01)$; for perseverance scale $(\mathrm{U}=15, \mathrm{p}<0.05)$; for self restrain scale $(U=17.5, p<0.05)$; and for GPA in career-oriented classes $(U=7, \quad p<0.01)$. The students with correlated low level of selfcontrol scored higher on subjective volitional control and had a considerably low GPA in careeroriented classes.

Correlation analysis results. According to the correlation analysis of the results of standardized methods used to measure subjective volitional control and GPA in career classes, there is a reverse relation between the general level of subjective volitional control and academic performance of students enrolled in physics and mathematics program $(\mathrm{r}=-0.33, \mathrm{p}<0.05)$ as well as a significant reverse relation between perseverance and academic performance of students taking classes in social studies and economics $(r=-0.63, p<0.05)$.
Correlation analysis of self-evaluation judgments, expert survey and GPA in careeroriented classes for the group of students with uncorrelated assessments of self-control indicates a direct relation between GPA, a high level of attentiveness evaluated by instructors $(\mathrm{r}=0.51$, $\mathrm{p}<0.01)$, and aggressiveness $(\mathrm{r}=0.39, \mathrm{p}<0.05)$. The analysis also shows a reverse relation between GPA in career-oriented classes, students judgments on the level of their perseverance $(r=-0.43 ; p<0.05)$, and the number of disciplinary offences $(r=-0.47 ; p<0.05)$.

Results of multiple regression analysis. The model developed for multiple regression analysis to measure the impact of the students' subjective volitional control, their intellectual abilities, motivation, and contentiousness on academic performance of students taking classes in social studies and economics turned out to be significant. The model describes $90 \%$ of dispersion and its multiple correlation coefficients are 0.94. Out of all variables under discussion, perseverance along with a certain level of intellectual abilities has the most significant impact on students' academic performance in career-oriented classes: beta coefficient $=0.6, \mathrm{p}=0.011$.

Within each program, the general group of students was divided into two subgroups: one subgroup where grades on career-oriented classes 
are higher than the average grade (academically successful students) and the second subgroup where grades are lower than the average grade (unsuccessful students). The regression model developed on the basis of the data of unsuccessful students sample describes more than $90 \%$ of dispersion and has significant multiple correlation coefficients. GPA in career-oriented classes is affected mostly by need for cognition (beta coefficient $=0.96, \quad \mathrm{p}=0.002$ ), subjective volitional control (beta coefficient $=0.9, \mathrm{p}=0.004$ ), and conscientiousness (beta coefficient $=0.46$, $\mathrm{p}=0.034$ ), whereas subjective volitional control is influenced by the level of self-control: beta coefficient $=0.7, \mathrm{p}=0.001$.

Regression analysis model based on the data of students with a moderately high score on selfcontrol describes more than $80 \%$ of dispersion. In career-oriented classes, GPA of students with a correlated high self-control is affected by low assessment of disciplinary offences (beta coefficient $=-0.6, p=0.031$ ).

The regression analysis model developed on the basis of the data of students who provided uncorrelated judgments describes more than $70 \%$ of dispersion. In this group of students, career-oriented classes' GPA is affected by high teacher's score on students' aggressiveness (beta coefficient $=0.7, p=0.000$ ) and attentiveness (beta coefficient $=0.53, \mathrm{p}=0.003$ ).

In the group of students enrolled into physics and mathematics program, perseverance is the most influential variable affecting selfcontrol indicators (beta coefficient $=0.37$, $\mathrm{p}=0.015$ ). Actualization of subjective volitional control encompasses a number of personal variables: attentiveness (beta coefficient $=0.53$, $\mathrm{p}=0.000$ ); a low level of impulsiveness (beta coefficient $=-0.44, p=0.002$ ), and aggressiveness (beta coefficient $=0.35, \mathrm{p}=0.014$ ). The multiple regression analysis suggests that self-control of students enrolled into social studies and economics program is affected by a low level of impulsiveness (beta coefficient $=-1, p=0.000$ ); perseverance (beta coefficient $=0.94, \mathrm{p}=0.004$ ); and (beta coefficient $=-0.6, p=0.011$ ).

\section{Discussion}

A high level of students' subjective volitional control, regardless of the program, reveals such personal characteristics as emotional maturity, activeness, independence, and self-sufficiency. Contentiousness, stability of intentions, realistic perception, and highly developed internal responsibility are necessary characteristics which ensure students ability to meet elevated standards of high school curriculum. The attained results match the outcome of contemporary investigation conducted by foreign researchers who also proved that self-control is crucial to achieve success (Mischel, 1988; Baumeister, 1994) and there is a relationship between many regulatory tasks and general personal resource which is close to the notion of energy or power(Mischel, 1988; Baumeister, 1994).

Thirty nine percent of high school students provided self-regulated learning assessments which correlated with teachers' evaluations. This points out that the students are able to adequately assess their volitional regulatory skills. A small percentage of students (10\%) have a low level of self-control and also are able to assess it realistically. The students, who scored low on self-control, have significantly lower GPA compared to the GPA of the students with high level of self-control. Thus, it can be concluded that, self-control is a vital personal characteristic which ensures academic success among high school students taking careeroriented classes.

The study revealed that $51 \%$ of high school students have uncorrelated and conflicting assessments of self-control indicators. Furthermore, students who provided correlated 
responses and scored low on assessments of self-control have a high score on volitional self-control (Эйдман \& Зверков, 2007). The obtained data points towards high school students' immaturity when assessing their volitional acts as well as their demonstration of constructed image of their volitional control when presenting their self-image. Academic performance of these students depends on students' level of confidence and external evaluations of their attentiveness by teachers. Academic performance of subjects with correlated high assessments of self-control is determined by how they evaluate their ability to meet external requirements.

Most of the students taking science classes have a high level of intellectual abilities. In these classes, self-control is closely related to general indicators of supraliminal subjective volitional control since students' perseverance in achieving set goals and their ability to control behavior drastically decrease impulsiveness and enhance students' general adaptability as well as their academic achievement. On the contrary, a high level of impulsiveness lowers students' adaptability which is expressed by misbehavior and inability to concentrate on academic achievement. It is necessary to point out that the impact of impulsiveness on volitional self-control is more noticeable among students taking classes on social studies and economics. From our perspective, this data corresponds with the established traditional opinion that "horizontal structure of volitional traits is based on inclinations, which are individual typological properties of the nervous system" (Ильин, 2009).

The results of the current study correspond with other researchers' findings (Kuhl, 1987; Смирнов, 2000) about the existence of various types of self-control and volitional efforts which are ensured by various mental functions and which typically realize themselves at a subconscious level(Kuhl, 1987). For instance, the students enrolled into social studies and economics classes commonly demonstrate attention control and emotional control, whereas students taking science classes show a higher level of effort activation control as well as behavioral control.

A reverse relation between indicators of subjective volitional control and academic performance on certain career-oriented classes can be explained, first of all, by the fact that the curricula require of students creativity, flexibility, and inventiveness rather than following a specified algorithm. Secondly, these results can be accounted for depletion of personal resources through self-regulation (Baumeister at al, 1994). A number of researchers believe that the loss of personal resources (known also as ego fatigue) is related to intellectual overstrain (Schmeichel, Vohs, \& Baumeister, 2003).

An increase in correlation between selfcontrol, motivation and conscientiousness among unsuccessful students might depict that high standards of curriculum require involvement of a great deal of personality mechanisms.

The academic performance of underachievers in career-oriented classes is affected by subjective volitional control as well as self-control which are determined by the level of formal and logical cognition; achievement motivation; a high level of conscientiousness; and need for cognition. Thus, the results of the current research reinforce the understanding accepted by Russian researchers that volitional effort is initiated by abilities and stimulated by a motivation sphere (Ильин, 2009). The obtained results correspond with the data of earlier research according to which there is a high relationship between college students' level of will and their interest to learning, attitude towards learning (Запорожец, 1986), 


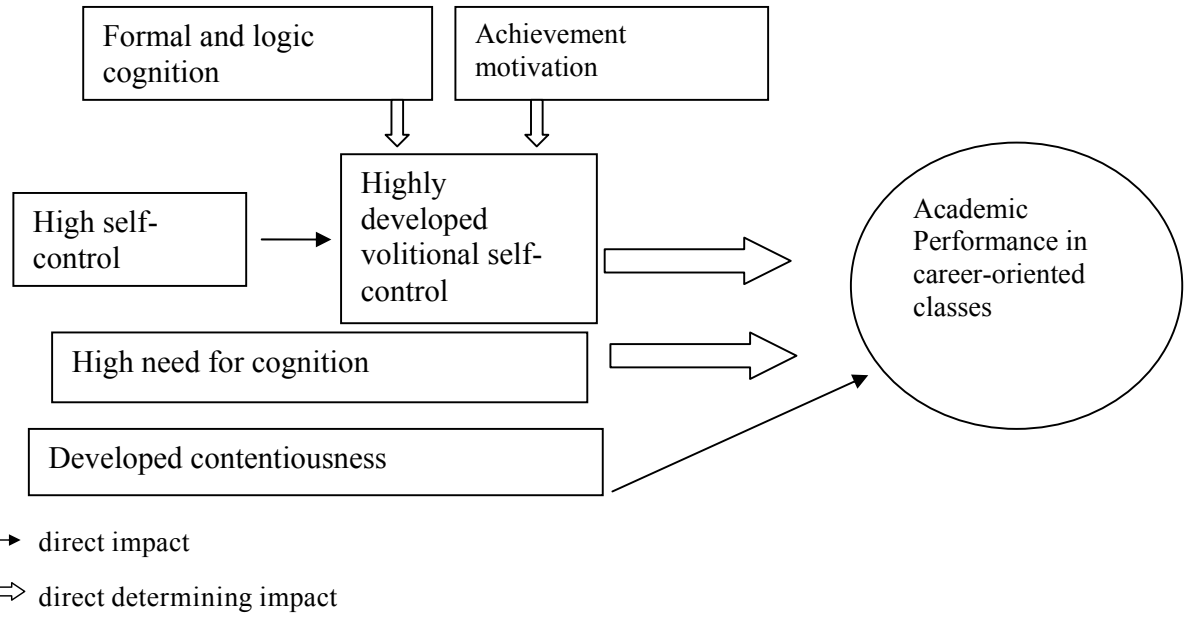

Fig. 1. The relationship between volitional self-regulation, motivation, and conscientious as predictors of academic success of underachievers in career-oriented classes

conscientiousness, achievement motivation, and life goals (Дементий \& Купченко, 2010).

\section{Conclusion}

We believe that our attempt to identify predictors of academic success in career-oriented classes have turned out to fruitful. Some of our results bear a polemical character and require further consideration and confirmation. However, even at this stage, the results of the current research can be applied to predict effectiveness of career-oriented education; and to consult students and their parents on how to establish constructive mental sets when choosing a school which provides career-oriented classes. The attained empirical results contribute to understanding personality mechanisms which ensure effectiveness of academic performance in high school and higher education. Within the current research discussion, the following questions pose interest for further research: types of students' self-control which come into play in the context of career-oriented education; dynamics of self-control in different phases of learning; characteristics of volitional selfregulation styles of students enrolled in careeroriented specializations, taking into account various intellectual and motivational factors.

1 In Russia, grading system has the following distribution of grades : A-5, B-4, C-3, F-2

\section{References}

1. Aleshina, Iu.E., Gozman L.Ia, \& Dubovskaia, E.M. Sotsial'no-psikhologicheskie metody issledovaniia supruzheskikhotnoshenii. Spetspraktikum po sotsial'noipsikhologii [Socio-psychological Research Methods of Marital Relationships. Special Practical Course of Social Psychology]. Moscow, MGU Publishing House, 1987, 80-85.

2. Batotsyrenov, V.B. (2013). Sootnoshenie vliianiia motivatsii potoka, lichnostnykh tsennostei $i$ volevogo kontrolia na akademicheskie dostizheniia studentov [The Ratio of the Influence of Motivation of the Flow, Personal Values and Will Control on the Academic Achievements of Students]. Mir nauki, kul'tury, obrazovaniia [The World of Science, Culture, Education], 5 (42), 3-7. 
3. Baumeister, R. F., Heatherton, T. F., \& Tice, D. M. (1994). Losing control: How and why people fail at self-regulation. San Diego: Academic Press, Inc.

4. Dementii, L.I., Kupchenko, V.E. Zhiznennye strategii: monografiia [Life Strategies: a Monograph]. Omsk, Omsk State University Publishing House, 2010, 192.

5. Iasiukova, L.A. Test struktury intellekta R. Amtkhauera (IST) [The Test Structures of Intelligence of R. Amthauer (IST)]. St. Petersburg: "IMATON", 2002, 80 p.

6. Il'in, E.P. Psikhologiia voli [Psychology of the Will]. St.-Petersburg, PITER, 2009, 368.

7. Gordeeva, T.S., Osin, E.N. (2012). Osobennosti motivatsii dostizheniia i uchebnoi motivatsii studentov, demonstriruiushchikh raznye tipy akademicheskikh dostizhenii (EGE, pobedy v olimpiadakh, akademicheskaia uspevaemost') [Features of Achievement Motivation and Learning Motivation of Students Who Demonstrate Different Types of Academic Achievements (United State Examination, Victory in Competitions, Academic Achievement). Psikhologicheskie issledovaniia [Psychological Research], Vol. 5 (24), No. 4, available at: http://psystudy.ru. 0421200116/0040.

8. Kochergina, E.V., Nye, J. V.K., \& Oriol, E.A. (2013). Faktory «Bol'shoi piaterki» kak psikhologicheskie prediktory akademicheskoi uspevaemosti studentov vuzov [Factors of the "Big Five" as Psychological Predictors of Academic Performance of University Students], Psikhologicheskie issledovaniia [Psychological Research], Vol. 6(27), No. 4, available at: http://psystudy.ru/index.php/ num/2013v6n27/776-kochergina27.htm

9. Ksenofontova, E.G. (1999). Issledovanie lokalizatsii kontrolia lichnosti - novaia versiia metodiki "Uroven' sub'ektivnogo kontrolia" [Study of Localization of the Personality Control - a New Version of "The Subjective Control Level" Method] Psikhologicheskii zhurnal [Psychological Journal], Vol. 20, No. 2, 103-114.

10. Kuhl, J. Action control: The maintenance of motivational states // F. Halish, J. Kuhl (eds.). Motivation, intention and volution. Berlin, 1987.

11. Mischel, W., Shoda, Y., \& Peake, P. K. (1988). The nature of adolescent competencies predicted by preschool delay of gratification. Journal of Personality and Social Psychology, 54, 687-696.

12. Morosanova, V.I., Fomina, T.G., \& Covas, Iu.V. (2014). Vzaimosviaz' reguliatornykh, intellektual'nykh i kognitivnykh osobennostei uchashchikhsia s matematicheskoi uspeshnost'iu [The Relationship of Regulatory, Intellectual and Cognitive Characteristics of Students Successful in Mathematics], Psikhologicheskie issledovaniia [Psychological Research], Vol. 7(34), No. 11, available at: http://psystudy.ru/index.php/num/2014v7n34/963-morosanova34.html

13. Oprosnik struktury temperamenta V.M. Rusalova. Praktikum po differentsial'noi psikhodiagnostike professional'noi prigodnosti [V.M. Rusalov's Questionnaire on the Structure of the Temperament. A Workshop on Differential Psychodiagnosis of Professional Competence]. Moscow, PER SE, 2003, 768.

14. Poropat A. A meta-analysis of the Five-factor model of personality and academic performance// Psychological Bulletin. 2009. Vol. 135(2). P. 322-338. doi: 10.1037/a0014996

15. Sikorskaia, G.A. (2008). Analiz izmenenii pedagogicheskoi sistemy pri perekhode $k$ profil'nomu obucheniiu [Analysis of Changes in the Educational System in the Transition to Specialized Education], Sibirskii pedagogicheskii zhurnal [Siberian Education Journal], No. 11, 323-331. 
16. Schmeichel, B. J., Vohs, K. D., \& Baumeister, R. F. (2003). Intellectual performance and ego depletion: Role of the self in logical reasoning and other information processing. Journal of Personality and Social Psychology,85, 33-46.

17. Smirnov, B.N. (2002). O raznykh podkhodakh $k$ probleme voli v psikhologii. Voprosy psikhologii [On the Different Approaches to the Issue of the Will in Psychology. Issues of Psychology], No. 3, 64-70.

18. Tangney, J. P., Baumeister, R. F., \& Boone, A. L. (2004). High self-control predicts good adjustment, less pathology, better grades, and interpersonal success. Journal of Personality, 72, 271322.

19. Zaporozhets, A.V. Izbrannye psikhologicheskie raboty [Selected Psychological Works]. Moscow, Pedagogy, 1986, 405

20. Zverkov, A.G., Eidman, E.V. Issledovanie volevoi samoreguliatsii. Psikhologicheskie metodiki izucheniia lichnosti: Praktikum [The Research of Willed Self-regulation. Psychological Methods of Studying Personality: a Practical Course]. Moscow, Os'-89, 2007, 100-106.

\section{Самоконтроль личности}

как предиктор успешности старшеклассников

в условиях профильного обучения

Л.И. Дементий, В.Е. Купченко

Омский государственный университет

им. Достоевского

Россия, 644077, Омск, пр. Мира, 55a

В статье приводится теоретический обзор исследований, отражающих корреляичию между интеллектуальными факторами, мотивачионными и личностными переменными c академической успеваемостью старшеклассников. Это эмпирическое исследование анализирует субъективное волевое управление, саморегулирование, мотивацию достижения, локус контроля, интеллектуальные способности итемпераментныехарактеристики, которые считаются важными факторами для прогнозирования успеваемости старшеклассников в контексте профессионального образования. Исследование указывает на разнииу между показателями стандартизированных методов самооценки, разработанных для студентов, и оценками студентов своего самоконтроля в процессе обучения. Результаты исследований показывают, что высокий уровень субъективного волевого контроля старшеклассников выступает существенным фактором для профессионального образования, в то время как саморегулирование является наиболее важным аспектом при обучении менее успешных студентов. Успеваемость студентов в профориентационных классах во многом зависит от их настойчивости и интеллектуальных способностей.

Ключевые слова: самоконтроль; профильное обучение.

Научная специальность: 19.00.00 - психологические науки. 